\title{
Ecophysiology of seed dormancy and germination in four Lonicera (Caprifoliaceae) species native to Korea
}

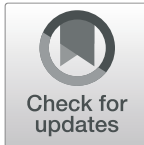

HyungBin Park ${ }^{1 \dagger}$, ChungHo Ko ${ }^{1 \dagger}$, SeungYoun Lee ${ }^{1,2+}$, SangYong Kim ${ }^{1}$, JongCheol Yang ${ }^{1}$ and KiCheol Lee ${ }^{1 *}$

\begin{abstract}
Background: To exploit the ornamental and medicinal purposes of Lonicera harae Makino, L. subsessilis Rehder, L. praeflorens Batalin, and L. insularis Nakai, native to Korea, it is necessary to understand their seed ecology for propagation. In this study, we investigated the seed dormancy type and germination characteristics of seeds of the four Korean native Lonicera species.

Results: The seeds of the four Lonicera species imbibed water readily, suggesting that the species do not have physical dormancy. Furthermore, the seeds exhibited underdeveloped embryos with only about $15-25 \%$ of the length of the seeds at dispersal. The embryos grew to the critical length with approximately $50-80 \%$ of the length of the seeds' development before radicle protrusion. Further, $94.4 \%$ and $61.1 \%$ of freshly matured seeds of $L$. insularis and $L$. harae germinated within 4 weeks after sowing at $15^{\circ} \mathrm{C}$ and $20^{\circ} \mathrm{C}$, respectively. Contrarily, $\mathrm{L}$. praeflorens and L. subsessilis seeds did not germinate within 4 weeks under all temperature treatments. At $15^{\circ} \mathrm{C}, \mathrm{L}$. praeflorens seeds started to germinate from 5 weeks and the final germination rate was $51.1 \%$ at 13 weeks. At $15^{\circ} \mathrm{C}$, L. subsessilis seeds started to germinate from 5 weeks after sowing and the final germination rate was $85.6 \%$ at 17 weeks after sowing. Embryo growth and germination of L. praeflorens and L. subsessilis occurred at a relatively high temperature $\left(\geq 15^{\circ} \mathrm{C}\right)$.

Conclusions: Overall, L. insularis seeds have only morphological dormancy. The seeds of L. harae have approximately $60 \%$ and $40 \%$ of morphological dormancy and morphophysiological dormancy, respectively. Contrarily, L. praeflorens and L. subsessilis exhibited non-deep simple-type morphophysiological dormancy that requires relatively high temperature $\left(\geq 15^{\circ} \mathrm{C}\right)$ for embryo growth and dormancy breaking. The optimum temperature for the germination of seeds of L. insularis, L. harae, L. praeflorens, and L. subsessilis was $15^{\circ} \mathrm{C}, 20^{\circ} \mathrm{C}$, $15^{\circ} \mathrm{C}$, and $20^{\circ} \mathrm{C}$, respectively. There was interspecific variation in seed dormancy and germination patterns in the four Lonicera species. The difference in these characteristics within the four Lonicera species could be useful for understanding the seed ecophysiological mechanisms of Lonicera species.
\end{abstract}

Keywords: Ecological adaption, Lonicera species, Morphological dormancy, Morphophysiological dormancy, Nondeep simple morphophysiological dormancy

\footnotetext{
* Correspondence: yloml@korea.kr

${ }^{\dagger}$ Hyung Bin Park, Chung Ho Ko and Seung Youn Lee contributed equally to this work.

'Division of Plant Resources, Korea National Arboretum, Yangpyeong 12519,

South Korea

Full list of author information is available at the end of the article
}

(c) The Author(s). 2019 Open Access This article is distributed under the terms of the Creative Commons Attribution 4.0 International License (http://creativecommons.org/licenses/by/4.0/), which permits unrestricted use, distribution, and reproduction in any medium, provided you give appropriate credit to the original author(s) and the source, provide a link to the Creative Commons license, and indicate if changes were made. The Creative Commons Public Domain Dedication waiver (http://creativecommons.org/publicdomain/zero/1.0/) applies to the data made available in this article, unless otherwise stated. 


\section{Background}

The genus Lonicera of the family Caprifoliaceae includes more than 200 species that are mostly arching shrubs or small trees cultivated as ornamental crops (Theis et al. 2008). Lonicera is mostly distributed in the Northern Hemisphere such as North America, Europe, and Asia (Naugžemys et al. 2007). Not only the plants, known as "honeysuckles," are useful resources for ornamental and medicinal purposes, but also their extracts can be used as a herbal medicine for inflammation in China (Theis et al. 2008; Ryuk et al. 2012; Yuan et al. 2012; Kim et al. 2016). There are 17 Lonicera species that are native to Korea (Lee 2003). Especially, L. insularis Nakai and $L$. subsessilis Rehder are Korean endemic plants that are distributed along the shore of Ulleungdo and from Pyeongannam-do to Jeollanam-do in Korea, respectively (Jeong et al. 2014; KNA 2019). To exploit these plant resources, investigating germination characteristics and seed dormancy type is needed.

Dormant seeds are viable seeds that do not germinate for a period of time even under environmental conditions that are favorable for germination, and thus, they can avoid unfavorable environmental conditions (FinchSavage and Leubner-Metzger 2006). Seed dormancy is divided into the following five categories: (1) physical dormancy (PY), (2) physiological dormancy (PD), (3) morphological dormancy (MD), (4) morphophysiological dormancy (MPD), and (5) combinational dormancy (PY+PD) (Baskin and Baskin 1998). Among them, seeds with MD and MPD have underdeveloped embryos during seed dispersal (Nikolaeva 1977; Baskin and Baskin 1998).

Seeds with MD have underdeveloped embryo and these seeds are not physiologically dormant (Baskin and Baskin 1998). Embryo of the seeds with MD must grow to a critical length before radicle protrusion. However, the seeds with MD do not require pretreatments for dormancy breaking; they only need time to grow full-sized embryo before radicle protrusion (Baskin and Baskin 2004a). Morphophysiological dormancy is a combination of MD and PD. Thus, MPD require time not only to grow embryo to a critical size, but also to break PD by cold and/or warm stratification. Morphophysiological dormancy in seeds is classified into eight types according to requirements of environmental conditions for seed dormancy breaking and embryo growth and germination responses to gibberellic acid (Baskin and Baskin 2004a).

From an ecological perspective, seed dormancy plays an important role in how germination timing is controlled in a natural habitat and how plants adapt to their natural environments (Geneve 2003). Thus, seed dormancy and germination requirements can provide insights into how plants determine where they can grow (Santiago et al. 2012). Furthermore, because the type of seed dormancy varies within the genus and species, classification of seed dormancy type among species in the same genus provides insights into how each species adapts to different natural habitats. In a previous study, the seeds of four Lonicera species native to North America were investigated to classify seed dormancy type (Hidayati et al. 2000b). The seeds of these species had MPD or MD or a combination of MD and MPD. Lonicera caerulea var. emphyllocalyx has only MD (Phartyal et al. 2009). On the contrary, L. fragrantissima has deep simple MPD and L. japonica has non-deep simple MPD (Baskin and Baskin 1998). Half of the seeds of L. maackii and L. morrowii have MD and the other half has nondeep simple MPD (Hidayati et al. 2000b; Santiago et al. 2012). However, seed dormancy and germination characteristics of Korean native Lonicera species have not been studied. The aim of the present study was to investigate seed dormancy type and germination characteristics of four Lonicera species native to Korea. These results will be useful to understand seed ecology and to identify optimum temperature treatments for propagating these Lonicera species.

\section{Materials and methods}

\section{Seed source}

To investigate the seed dormancy type and germination characteristics of the four Lonicera species, the fruits of these species were collected from 2016 to 2017. The seeds of L. insularis were collected in June 2016 from plants growing in Ulleungdo, Korea. The seeds of $L$. subsessilis Rehder were collected in September 2016 from plants growing in the Korea National Arboratum, Pocheon, Korea. The seeds of $L$. harae Makino and $L$. praeflorens Batalin were collected in May 2017 from plants growing in the Korea National Arboratum, Pocheon, Korea. The seeds were removed from the pulp and dried at ambient room temperature (approximately $25^{\circ} \mathrm{C}$ ) for 1-2 weeks, packed and sealed plastic containers, and stored at $4{ }^{\circ} \mathrm{C}$ until further analyses.

\section{Water imbibition test}

To investigate the PY of the seeds, a water imbibition test was conducted on March 4, 2018. Three replicates of 20 seeds each were used. The dry matter of the seeds was measured, and then the seeds were placed in 9-cmdiameter Petri dishes (Cell Culture Dish; SPL Life Sciences Co., Ltd., Gyeonggi-do, Korea) with two layers of filter papers (Whatman No.2; GE Healthcare, Buckinghamshire, UK) moistened with distilled water. The seeds were incubated at room temperature (approximately $25^{\circ} \mathrm{C}$ ). The fresh weight of seeds was measured after 3 , $6,9,12,24$, and $48 \mathrm{~h}$ of incubation. The water uptake by seeds was calculated using the water uptake formula (Baskin et al. 2004b). 
Water absorption $(\%)=\left[\left(W_{2}-W_{1}\right) / W_{1}\right] \times 100$

where, $W_{2}$ is the mass of the seeds after imbibition for a given interval and $W_{1}$ is the initial seed mass.

\section{Seed morphology}

To investigate MD, the seed morphology measurement was carried out on April 5, 2018 to June 12, 2018. The seeds of $L$. insularis and $L$. praeflorens were incubated at $15^{\circ} \mathrm{C}$, whereas the seeds of $L$. harae and L. subsessilis were incubated at $20^{\circ} \mathrm{C}$. The seeds were halved using a razor blade (stainless blade; Dorco, Seoul, KR), and then the length of the embryo of the seeds at dispersal and just before germination was measured using a USB microscope (AM 3111 Dino-Lite Premier; AnMo Electronics Co., Taiwan). Thereafter, the embryo/seed ratio (E:S ratio) was calculated and compared between seed dispersal and just before germination.

\section{Temperature treatments}

To investigate the seed dormancy type and optimum temperatures for germination, temperature experiments were carried out from May 25, 2017, to December 8, 2017. Three replicates with 30 seeds were used. The seeds were placed on two sheets of filter papers moistened with distilled water in 9-cm-diameter Petri dishes. All Petri dishes were sealed with Parafilm (PM-996; Bemis Company Inc., USA) to reduce water loss during incubation. Temperature and light-controlled multiroom chambers (WIM-R L4; Daihan scientific Co. Ltd., Wonju, Korea) were used in this experiment. The growth chambers were set at constant temperatures of $5^{\circ} \mathrm{C}, 15^{\circ} \mathrm{C}, 20^{\circ} \mathrm{C}$ and $25^{\circ} \mathrm{C}$ and 12 -h light/dark photoperiod using cool white fluorescent lamps, producing a

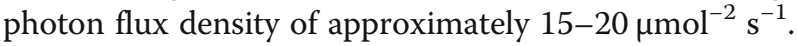

For $L$. subsessilis, seasonal temperature cycling treatment known as move-along experiment was performed from May 25, 2017 to February 10, 2018 (Baskin and Baskin 2003). In the move-along experiment, one set (move A treatment) of seeds was placed at $5{ }^{\circ} \mathrm{C}$. After 12 weeks, they were moved from $5{ }^{\circ} \mathrm{C}$ to $15^{\circ} \mathrm{C}$ (4 weeks) $\rightarrow 20^{\circ} \mathrm{C}$ (4 weeks) $\rightarrow 25^{\circ} \mathrm{C}$ (12 weeks). The second set (move B treatment) of seeds was placed initially at $25^{\circ} \mathrm{C}$. After 12 weeks, they were moved from $25^{\circ} \mathrm{C}$ to $20^{\circ} \mathrm{C}(4$ weeks) $\rightarrow 15^{\circ} \mathrm{C}$ ( 4 weeks) $\rightarrow 5^{\circ} \mathrm{C}$ ( 12 weeks). The germinated seeds were counted every week and removed from the Petri dishes. Sterilized water was frequently supplied to the Petri dishes to maintain moist condition. Rotten seeds were removed and excluded from the calculation of germination rate.

\section{Statistical analysis}

Statistical Analysis System (SAS) version 9.4 (SAS Institute Inc., Cary, NC, USA) was used for statistical analyses of the data. Differences between the mean final germination rate of seed under four temperature treatments were assessed using Tukey's honestly significant difference tests. Differences between the E:S ratio of seeds at seed dispersal and just before germination were assessed using paired $t$ tests. The results with $p$ values $<$ 0.05 were considered statistically significant.

\section{Results \\ Water imbibition test}

The mass of the seeds of $L$. insularis, $L$. harae, L. praeflorens, and L. subsessilis was increased by approximately $50 \%, 90 \%, 35 \%$, and $40 \%$ after $3 \mathrm{~h}$ of water imbibition and more than $60 \%, 170 \%, 50 \%$, and $70 \%$ after $48 \mathrm{~h}$ of water imbibition, respectively (Fig. 1).

\section{Seed morphology}

The seeds of the four Lonicera species has undeveloped embryo at dispersal (Table 1). The E:S ratio of the seeds of $L$. insularis, $L$. praeflorens, $L$. harae, and $L$. subsessilis at dispersal was $0.26 \pm 0.02,0.13 \pm 0.07,0.14 \pm 0.01$, and $0.16 \pm 0.01 \mathrm{~mm}$, respectively. The E:S ratio of the seeds of the four Lonicera species just before germination was $0.82 \pm 0.04,0.81 \pm 0.02,0.46 \pm 0.13$, and $0.74 \pm 0.01 \mathrm{~mm}$, respectively (Fig. 4).

\section{Temperature treatments}

The seeds of the four Lonicera species presented different germination characteristics under the four temperature treatments (Fig. 2). The seeds of the four Lonicera species did not germinate at $5{ }^{\circ} \mathrm{C}$. At $15^{\circ} \mathrm{C}$, the freshly matured seeds of $L$. insularis and $L$. harae germinated to $94.4 \%$ and $61.1 \%$ at 4 weeks after sowing, respectively. The final germination rate of the seeds of $L$. harae was $81.1 \%$ at 23 weeks after sowing at $15^{\circ} \mathrm{C}$ (Fig. 2) . On the contrary, the seeds of $L$. praeflorens and $L$. subsessilis did not germinate at the four temperature regimes within 4 weeks after sowing at all temperature regimes. At $15^{\circ} \mathrm{C}$, the seeds of $L$. pareflorens and $L$. subsessilis started to germinate from 5 weeks after sowing and the final germination rate of the seeds was $51.1 \%$ and $80.0 \%$ at 13 and 17 weeks after sowing, respectively (Fig. 2). At $20^{\circ} \mathrm{C}$, the seeds of $L$. insularis and L. harae germinated to $88.9 \%$ and $61.1 \%$ at 4 weeks after sowing, respectively, and the final germination rate of $L$. harae was $97.8 \%$ at 16 weeks after sowing (Fig. 2). At $20^{\circ} \mathrm{C}$, the seeds of L. praeflorens and L. subsessilis started to germinate from 8 and 9 weeks after sowing, respectively, and the final germination rate of the seeds was $40.0 \%$ and $85.6 \%$ at 19 and 14 weeks after sowing, respectively (Fig. 2). At $25^{\circ} \mathrm{C}$, the final germination rate of L. insularis, L. harae, and L. subsessilis was $73.3 \%, 67.8 \%$, and $76.7 \%$ at 9,27 , and 27 weeks after sowing, respectively. Contrarily, the seeds of $L$. praeflorens did not germinate at $25^{\circ} \mathrm{C}$ during incubation (Fig. 2). 


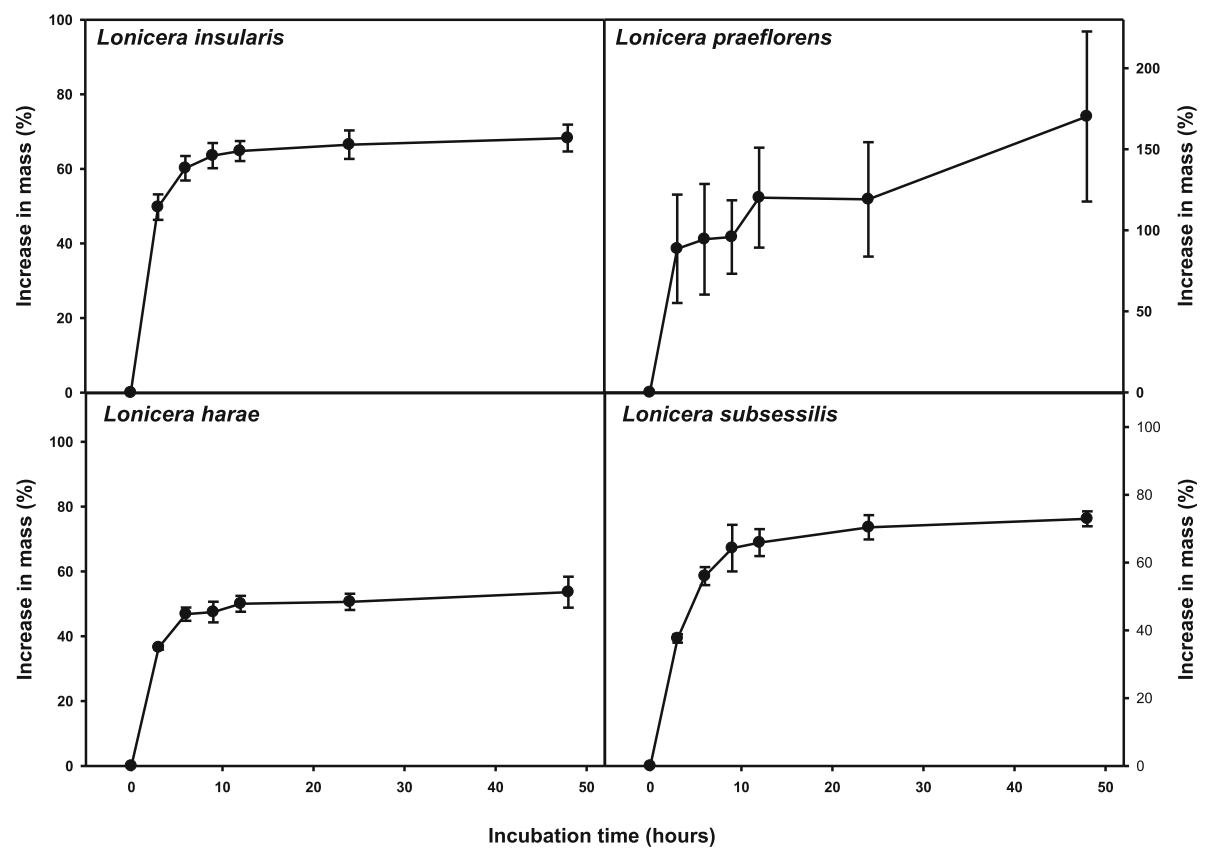

Fig. 1 Water uptake by intact seeds of Lonicera insularis Nakai, Lonicera praeflorens Batalin, Lonicera harae Makino, and Lonicera subsessilis Rehder with increase in mass. Seeds were incubated at ambient room temperature (approximately $25^{\circ} \mathrm{C}$ ) on filter papers moistened with distilled water for $48 \mathrm{~h}$. The vertical error bars represent SE $(n=3)$

\section{Move-along experiments}

In the move-along experiment of L. subsessilis, the seeds of move A treatment (start of winter) did not germinate until 24 weeks after sowing. Germination was initiated from 5 weeks after moving the seeds from $20^{\circ} \mathrm{C}$ to $25^{\circ} \mathrm{C}$, and the final germination rate of the seeds was $74.4 \%$ at 29 weeks after sowing (Fig. 3). The seeds of move B treatment (start of summer) started to germinate from 3 weeks after moving the seeds from $25^{\circ} \mathrm{C}$ to $20^{\circ} \mathrm{C}$, and the final germination rate of the seeds was $83.3 \%$ at 16 weeks after sowing. The final germination rate of the seeds of move B treatment was higher than that of the seeds of move A treatment (Fig. 3).

\section{Discussion}

In general, the germination of seeds with PY is prevented by water impermeability of the seeds or fruit coats due to the presence of water-impermeable palisade layers of cells (Baskin and Baskin 2004b). If the mass of seeds increases to $\leq 20 \%$ in the water imbibition test, the seeds are considered impermeable to water (Baskin and Baskin 2003). This dormancy can be broken by mechanical or chemical scarification such as dry heating, dipping in boiling water, and treating with sulfuric acid (Baskin et al. 2004; Finch-Savage and Leubner-Metzger 2006; De Souza et al. 2012). In the present study, the seeds of the four Lonicera species imbibed water readily, suggesting that the species have no PY.
Several previous studies have reported that the seeds of Lonicera species have undeveloped embryo at dispersal (Martin 1946; Hidayati et al. 2000a; Hidayati et al. 2000b). In this study, we found that the embryo of the four Lonicera species was small and undeveloped, and they grew to the critical length before radicle protrusion. In general, underdeveloped embryo requires time to grow to the critical length. This indicates that the seeds of the species have MD or MPD (Baskin and Baskin 1998; Baskin and Baskin 2004b).

According to Baskin and Baskin (2004b), seeds with MD germinate within about 30 days. Thus, the seeds of L. insularis have only MD. On the contrary, approximately $60 \%$ and $40 \%$ of the seeds of $L$. harae exhibited MD and MPD, respectively. In the case of L. praeflorens, the germination of seeds was initiated at a relatively high temperature $\left(15^{\circ} \mathrm{C}\right)$ from 5 weeks after sowing. At a high temperature $\left(25^{\circ} \mathrm{C}\right)$, the seeds of $L$. praeflorens did not germinate during incubation. At $15^{\circ} \mathrm{C}$, the seeds of $L$. subsessilis started to germinate from 5 weeks after sowing and the final germination rate was $80.0 \%$ at 17 weeks after sowing. At $20{ }^{\circ} \mathrm{C}$, the seeds started to germinate from 9 weeks after sowing and the final germination rate was $85.6 \%$ at 14 weeks after sowing. The seeds of $L$. praeflorens and L. subsessilis did not germinate within 4 weeks after sowing (Fig. 2). Thus, the seeds of these two species have MPD.

Morphophysiological dormancy is subdivided into eight types (Nikolaeva 1977; Baskin and Baskin 1998; 
Table 1 Internal seed morphology of four Lonicera species native to Korea. Undeveloped embryos at dispersal and fully developed embryos just before germination are shown. pr pericarp, sc seed coat, en endosperm, em embryo. Scale bars represent $1 \mathrm{~mm}$

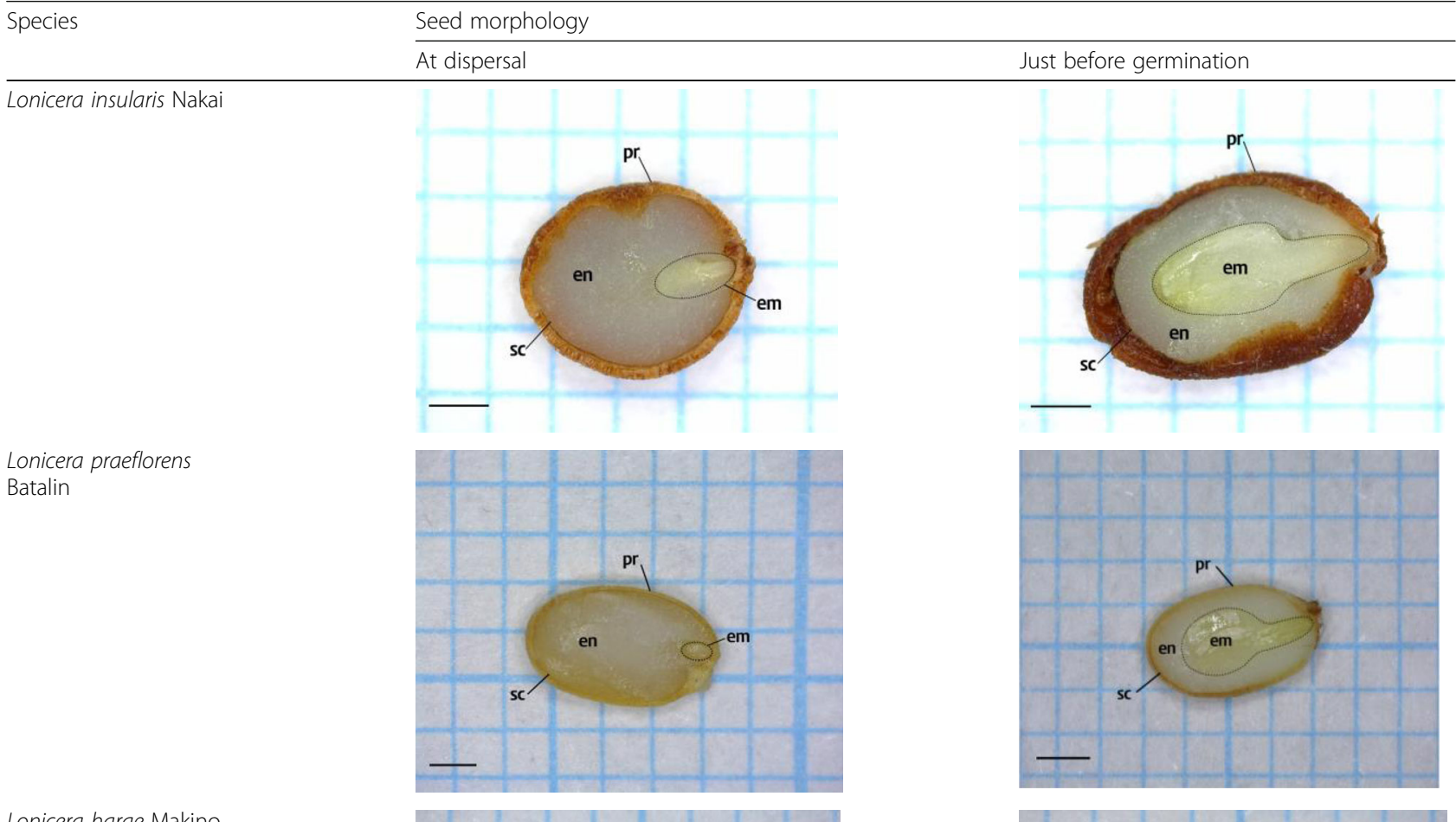

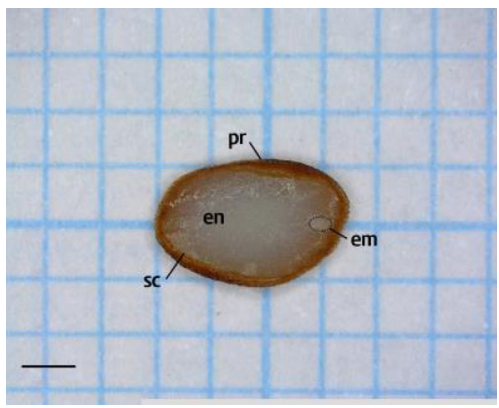

Lonicera subsessilis Rehder

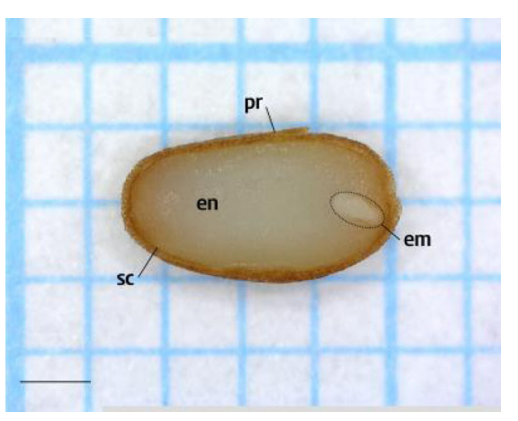

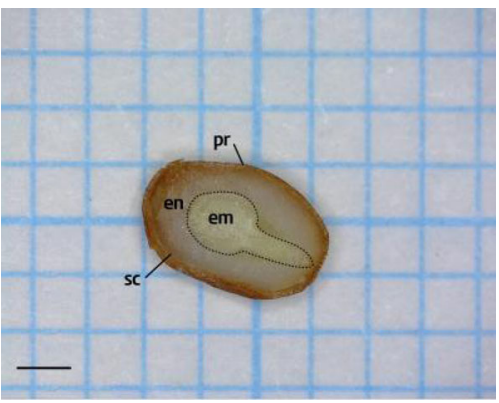

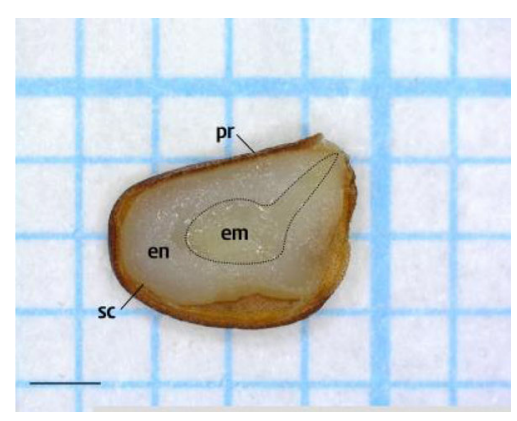

Walck et al. 2002; Baskin and Baskin 2004b). It is broadly divided into the following two categories: (1) simple-type MPD that requires relatively high temperature $\left(\geq 15^{\circ} \mathrm{C}\right)$ for embryo growth and (2) complex-type MPD that requires only low temperature $\left(0-10^{\circ} \mathrm{C}\right)$ for embryo growth (Baskin and Baskin 1998; Hidayati et al. 2000b). The simple and complex MPD can be sub-divided based on the level of PD: non-deep, intermediate, and deep. Non-deep simple MPD requires warm or cold stratification to break dormancy. Intermediate and deep simple MPD require warm stratification followed by cold stratification to break PD (Nikolaeva 1977; Baskin and Baskin 1998; Hidayati et al. 2000b). In a previous study, L. fragrantissima, L. japonica, L. maackii, and L. morrowii have been reported to have MPD. L. fragrantissima had deep simple MPD and required warm plus cold stratification to break PD. $L$. japonica, L. maackii, and L. morrowii had non-deep simple 


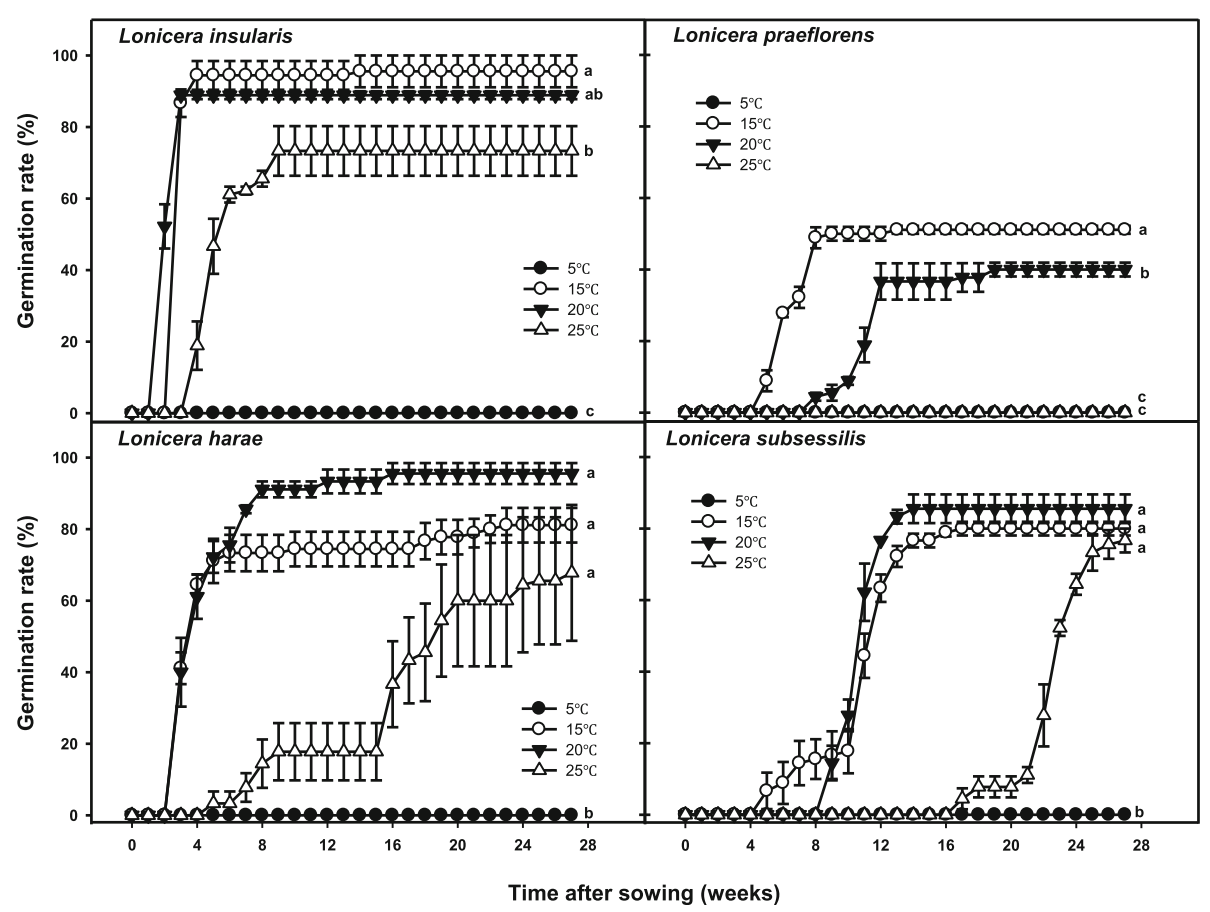

Fig. 2 Cumulative germination percentage in seeds of Lonicera insularis Nakai, Lonicera praeflorens Batalin, Lonicera harae Makino, and Lonicera subsessilis Rehder at four constant temperatures $\left(5^{\circ} \mathrm{C}, 15^{\circ} \mathrm{C}, 20^{\circ} \mathrm{C}\right.$, and $\left.25^{\circ} \mathrm{C}\right)$. The vertical error bars represent $\mathrm{SE}(n=3)$. The different letters represent statistically significant differences, as determined by Tukey's HSD tests $(p<0.05)$

MPD that required stratification (warm or cold) to break PD, in which about $50 \%$ of the seeds of $L$. maackii and L. morrowii had only MD (Hidayati et al. 2000b). Approximately $50 \%$ of the seeds of $L$. praeflorens require only relatively high temperature $\left(15^{\circ} \mathrm{C}\right)$ to grow embryo and germinate without cold stratification, whereas approximately $50 \%$ did not germinate during the experiment. Thus, approximately $50 \%$ of the seeds of $L$. praeflorens is estimated to have non-deep simple-type MPD. Because approximately $50 \%$ of the seeds of $L$. praeflorens did not germinate in this study, further studies are needed to accurately classify dormancy type in ungerminated seeds. Germination and embryo growth of L. subsessilis seeds occurred only at relatively high temperature $\left(\geq 15^{\circ} \mathrm{C}\right)$ without cold stratification. In the move-along experiment, the seeds of $L$. subsessilis germinated from 3 weeks after moving them from 25 to $20^{\circ} \mathrm{C}$ in move B treatment (start of summer), whereas the seeds in move A treatment (start of winter) germinated from 5 weeks after moving them from 20 to $25^{\circ} \mathrm{C}$. The result of move $\mathrm{B}$ treatment was similar to that at $25^{\circ} \mathrm{C}$ (Fig. 3). The seeds of move A treatment did not germinate until 12 weeks after sowing at $5{ }^{\circ} \mathrm{C}$, and the seeds started to germinate after exposure to relatively high temperature. Thus, $85.6 \%$ of $L$. subsessilis seeds is also considered to have non-deep simple MPD. The seeds of the four Lonicera species showed a variation in time to germination. Various states of dormancy within the same seed population result in a slow germination rate which is an ecologically advantageous strategy for unpredictable environmental conditions (Doussi and Thanos 2002).

In a previous study, the dispersal pattern of four Lonicera seeds corresponded with their dormancy and germination patterns (Hidayati et al. 2000b). The seeds of $L$. insularis are dispersed from late July to August (late summer) in the natural environment. In the present study, they were exposed to temperatures that are considered optimum $\left(15-20^{\circ} \mathrm{C}\right)$ for germination. Because the dispersed seeds have only MD, they will germinate within 30 days after dispersal; however, if the seeds are dispersed under high temperature conditions $\left(\geq 25^{\circ} \mathrm{C}\right)$, their germination will be delayed. The seeds of $L$. harae are dispersed from June. When the seeds are exposed to relatively high temperature $\left(20^{\circ} \mathrm{C}\right)$, which was considered optimum for germination in this study, approximately $60 \%$ of the seeds will germinate within 30 days after dispersal as they have approximately $60 \% \mathrm{MD}$ and the remaining will germinate within 16 weeks. The seeds of $L$. praeflorens begin to disperse from June, and then they are exposed to warm stratification. Because the optimum temperature to germinate is $15^{\circ} \mathrm{C}$, than $20^{\circ} \mathrm{C}$, germination of the dispersed seeds can be delayed. The seeds of $L$. subsessilis are dispersed from late September 


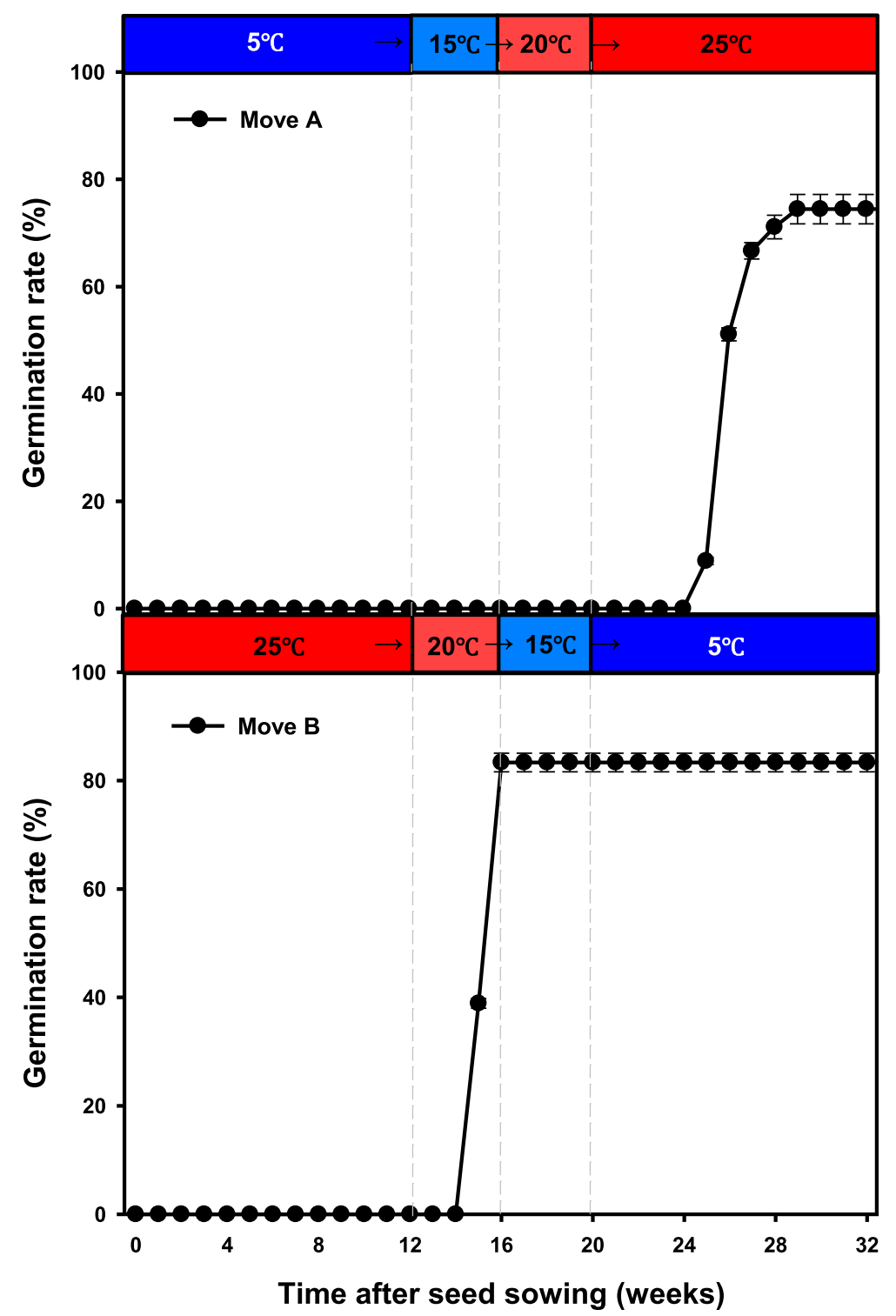

Fig. 3 Cumulative germination rate of Lonicera subsessilis Rehder seeds in the move-along experiment. Move A started at $5^{\circ} \mathrm{C}\left(5^{\circ} \mathrm{C}(12\right.$ weeks $\rightarrow \rightarrow$ $15^{\circ} \mathrm{C}\left(4\right.$ weeks) $\rightarrow 20^{\circ} \mathrm{C}$ ( 4 weeks) $\rightarrow 25^{\circ} \mathrm{C}\left(12\right.$ weeks)). Move B started at $25^{\circ} \mathrm{C}\left(25^{\circ} \mathrm{C}\right.$ (12 weeks) $\rightarrow 20^{\circ} \mathrm{C}$ ( 4 weeks) $\rightarrow 15^{\circ} \mathrm{C}\left(4\right.$ weeks) $\rightarrow 5^{\circ} \mathrm{C}(12$ weeks)). The vertical bars represent SE $(n=3)$

to early October (in autumn). They might be exposed to relatively high temperatures before germination. Thus, they will germinate via exposure to relatively high temperature $\left(\geq 15^{\circ} \mathrm{C}\right)$ in the early autumn. If they are exposed to low temperatures, germination will be delayed until they are exposed to a relatively high temperature $\left(\geq 15^{\circ} \mathrm{C}\right)$, as evidenced in seeds of the move A treatment (start of winter) in the move-along experiment.

In the same genus and species, seed dormancy can vary according to the native habitat (Hidayati et al. 2000a). There was stasis of ecophysiological traits such as seed dormancy and germination and ecological divergence in seed dormancy and germination characteristics of the disjunct species of the genera Viburnum and Siphisia (Adams et al. 2005; Walck et al. 2012). The disjunct species Osmorhiza and Erythronium have different seed dormancy. Osmorhiza chilensis, Osmorhiza occidentalis, and Erythronium grandiflorum have deep complex MPD, whereas Osmorhiza longistylis, Osmorhiza claytonii, Erythronium albidum, and Erythronium americanum have non-deep complex MPD (Baskin and Baskin 1984; Baskin and Baskin 1991; Baskin et al. 1995) . In the present study, the four Lonicera species exhibited common morphological traits such as undeveloped embryo. However, there was ecological divergence in seed dormancy and germination characteristics. 


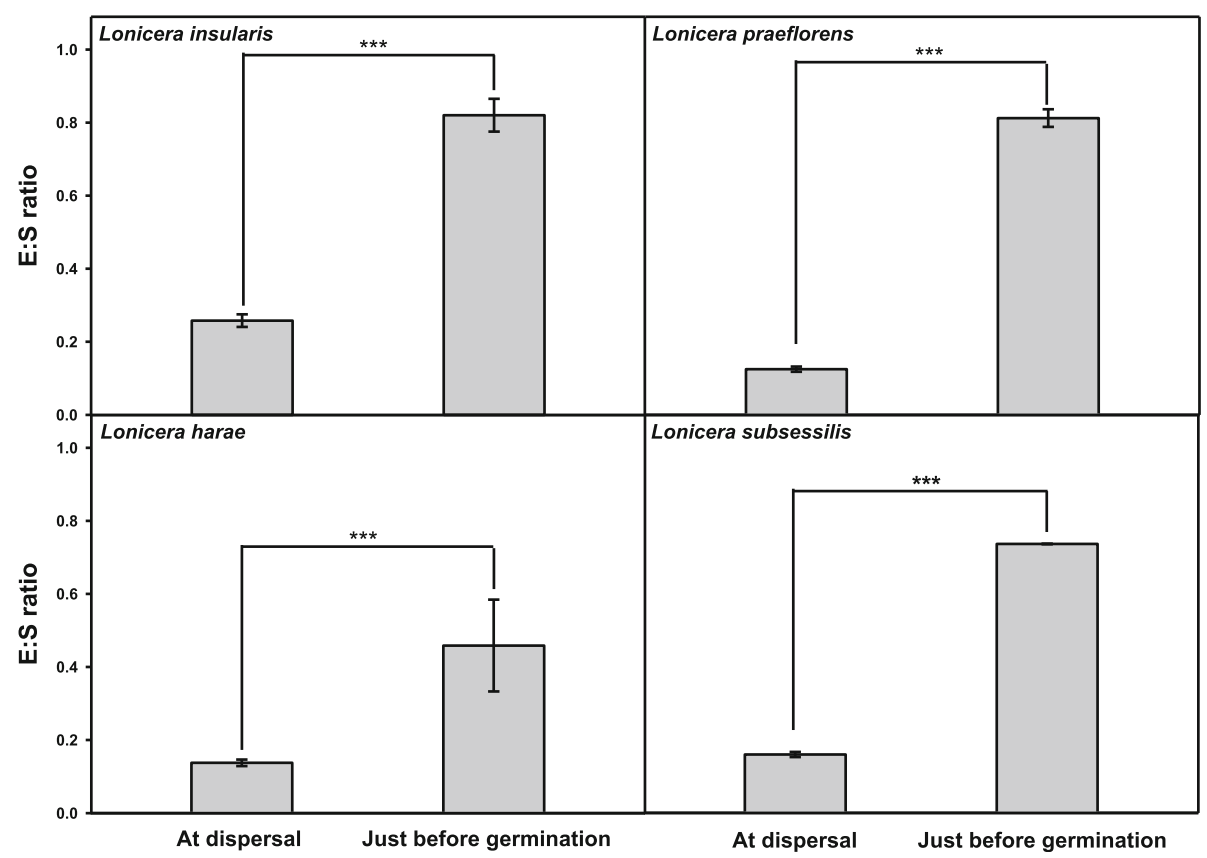

Fig. 4 Embryo/seed ratio (E:S ratio) in the seeds of Lonicera insularis Nakai, Lonicera praeflorens Batalin, Lonicera harae Makino, and Lonicera subsessilis Rehder at seed dispersal and at just before germination. The seeds of $L$. insularis, L. praeflorens, L. harae, and L. subsessilis were incubated at $15^{\circ} \mathrm{C}, 15^{\circ} \mathrm{C}, 20^{\circ} \mathrm{C}$, and $25^{\circ} \mathrm{C}$, respectively. The vertical error bars represent $\mathrm{SE}(n=3)$. Each E:S ratio at dispersal and just before germination was compared using paired $t$ test. ${ }^{* *} p<0.001$

\section{Conclusion}

The results of this study revealed that the seeds of $L$. insularis have only MD and the seeds of $L$. harae have approximately $60 \%$ MD and 40\% MPD. On the contrary, the seeds of $L$. praeflorens and $L$. subsessilis have nondeep simple-type MPD that requires only relatively high temperature $\left(\geq 15^{\circ} \mathrm{C}\right)$ for embryo growth and dormancy breaking. The optimum temperature for the germination of seeds of $L$. insularis, $L$. harae, $L$. praeflorens, and $L$. subsessilis was $15^{\circ} \mathrm{C}, 20^{\circ} \mathrm{C}, 15^{\circ} \mathrm{C}$, and $20^{\circ} \mathrm{C}$, respectively (Fig. 4). There was interspecific variation in seed dormancy and germination in the four Lonicera species. Our results will be useful for understanding seed ecophysiological mechanisms in a habitat and propagating Lonicera species.

\section{Abbreviations}

E:S ratio: Embryo/seed ratio; MD: Morphological dormancy; MPD: Morphophysiological dormancy; PD: Physiological dormancy; PY: Physical dormancy

\section{Acknowledgements}

We thank Dohyun Kim and Kyusung Choi for the assistance in the field sample collections and observations. We also thank the anonymous reviewers for providing helpful comments on this paper.

\section{Authors' contributions}

PHB, GCH, and LSY analyzed the data and wrote the manuscript. LKC designed the study and analyzed the data. YJC and KSY designed the study and coordinated the overall research. All authors read and approved the final manuscript.

\section{Funding}

This study was funded by the project "Useful Plant Collection and Development of Mass Propagation Protocol for the Establishment of Foundation of Convergence Platform using Forest Plants (KNA1-2-25, 16-3)" funded by the Korea National Arboretum.

\section{Availability of data and materials}

The datasets used and/or analyzed in the present study are available from Author1 (phb1274@ korea.kr) on reasonable request.

Ethics approval and consent to participate Not applicable.

\section{Consent for publication}

Not applicable.

\section{Competing interests}

The authors declare that they have no competing interests.

\section{Author details}

'Division of Plant Resources, Korea National Arboretum, Yangpyeong 12519, South Korea. ${ }^{2}$ Division of Horticulture \& Medicinal Plant, Andong National University, Andong 36729, South Korea.

Received: 4 April 2019 Accepted: 20 May 2019

Published online: 21 June 2019

\section{References}

Adams CA, Baskin JM, Baskin CC. Trait stasis versus adaptation in disjunct relict species: evolutionary changes in seed dormancy-breaking and germination requirements in a subclade of Aristolochia subgenus Siphisia (Piperales). Seed Sci Res. 2005;15:161-73.

Baskin CC, Baskin JM. Seeds: ecology, biogeography, and, evolution of dormancy and germination. San Diego: Academic; 1998.

Baskin CC, Baskin JM. When breaking seed dormancy is a problem try a movealong experiment. Nat Plants J. 2003;4:17-21. 
Baskin CC, Baskin JM. Germination seeds of wildflowers, an ecological perspective. HortTechnology. 2004a;14:467-73.

Baskin CC, Meyer SE, Baskin JM. Two types of morphophysiological dormancy in seeds of two genera (Osmorhiza and Erythronium) with an Arcto-Tertiary distribution pattern. Am J Bot. 1995;82:293-8.

Baskin JM, Baskin CC. Germination ecophysiology of the woodland herb Osmorhiza longistylis (Umbelliferae). Am J Bot. 1984;71:687-92.

Baskin JM, Baskin CC. Nondeep complex morphophysiological dormancy in seeds of Osmorhiza claytonii (Apiaceae). Am J Bot. 1991;78:588-93.

Baskin JM, Baskin CC. A classification system for seed dormancy. Seed Sci Res. 2004b;14:1-16.

Baskin JM, Davis BH, Baskin CC, Gleason SM, Cordell S. Physical dormancy in seeds of Dodonaea viscosa (Sapindales, Sapindaceae) from Hawaii. Seed Sci Res. 2004;14:81-90.

De Souza TV, Voltolini CH, Santos M, Paulilo MTS. Water absorption and dormancy-breaking requirements of physically dormant seeds of Schizolobium parahyba (Fabaceae-Caesalpinioideae). Seed Sci Res. 2012;22:169-76.

Doussi MA, Thanos CA. Ecophysiology of seed germination in Mediterranean geophytes. 1. Muscari spp. Seed Sci Res. 2002;12:193-201.

Finch-Savage WE, Leubner-Metzger G. Seed dormancy and the control of germination. New Phytol. 2006;171:501-23.

Geneve RL. Impact of temperature on seed dormancy. HortScience. 2003;38:336-40.

Hidayati SN, Baskin JM, Baskin CC. Dormancy-breaking and germination requirements for seeds of Diervilla lonicera (Caprifoliaceae), a species with underdeveloped linear embryos. Can J Bot. 2000a;78:1199-205.

Hidayati SN, Baskin JM, Baskin CC. Dormancy-breaking and germination requirements of seeds of four Lonicera species (Caprifoliaceae) with underdeveloped spatulate embryos. Seed Sci Res. 2000b;10:459-69.

Jeong KS, Kim MS, Lee W, Park JH. Intraspecific variation and geographic study of Lonicera insularis (Caprifoliaceae) based on chloroplast DNA sequences. Kor J PI Taxon. 2014;44:202-7.

Kim SM, Won YH, Jeong K, Kim MJ, Chun WJ, Yang HJ, Kwon YS. Chemical constituents of Lonicera maackii leaves. Kor J Pharmacogn. 2016;47:117-21.

Korea National Arboretum. 2019. http://www.nature.go.kr. Accessed 25 Jan 2019.

Lee TB. Coloured flora of Korea. Hyangmunsa, Seoul; 2003.

Martin AC. The comparative internal morphology of seeds. Am Midl Naturalist. 1946:36:513-660

Naugžemys D, Žilinskaitė S, Denkovskij J, Patamsytė J, Literskis J, Žvingila D. RAPD based study of genetic variation and relationships among Lonicera germplasm accessions. Biologija. 2007;53:34-9.

Nikolaeva MG. Factors controlling the seed dormancy pattern. In: The physiology and biochemistry of seed dormancy and germination (ed. A. A. Khan). Amsterdam: North-Holland Publishing. 1977. p. 51-74.

Phartyal SS, Kondo T, Baskin JM, Baskin CC. Temperature requirements differ for the two stages of seed dormancy break in Aegopodium podagraria (Apiaceae), a species with deep complex morphophysiological dormancy. Am J Bot. 2009;96:1086-95.

Ryuk JA, Lee HW, Ko BS. Discrimination of Lonicera japonica and Lonicera confusa using chemical analysis and genetic marker. Kor J Herbology. 2012;27:15-21.

Santiago A, Herranz JM, Copete E, Ferrandis P. Species-specific environmental requirements to break seed dormancy: implications for selection of regeneration niches in three Lonicera (Caprifoliaceae) species. Bot. 2012;91:225-33.

Theis N, Donoghue MJ, Li J. Phylogenetics of the Caprifolieae and Lonicera (Dipsacales) based on nuclear and chloroplast DNA sequences. Syst Bot. 2008:33:776-83

Walck JL, Hidayati SN, Okagami N. Seed germination ecophysiology of the Asian species Osmorhiza aristata (Apiaceae): comparison with its North American congeners and implications for evolution of types of dormancy. Am J Bot. 2002:89:829-35.

Walck JL, Karlsson LM, Milberg P, Hidayati SN, Kondo T. Seed germination and seedling development ecology in world-wide populations of a circumboreal Tertiary relict. AoB plants. 2012;2012:pls007.

Yuan Y, Song L, Li M, Liu G, Chu Y, Ma L, Zhou Y, Wang X, Gao W, Qin S, Yu J, Wang $X$, Huang L. Genetic variation and metabolic pathway intricacy govern the active compound content and quality of the Chinese medicinal plant Lonicera japonica thunb. BMC Genomics. 2012;13:195.

\section{Publisher's Note}

Springer Nature remains neutral with regard to jurisdictional claims in published maps and institutional affiliations.

\section{Ready to submit your research? Choose BMC and benefit from}

- fast, convenient online submission

- thorough peer review by experienced researchers in your field

- rapid publication on acceptance

- support for research data, including large and complex data types

- gold Open Access which fosters wider collaboration and increased citations

- maximum visibility for your research: over $100 \mathrm{M}$ website views per year

At $\mathrm{BMC}$, research is always in progress.

Learn more biomedcentral.com/submissions 